\title{
MICROSOMAL SUPEROXIDE ANION PRODUCTION AND NADPH-OXIDATION IN A SERIES OF 22 AZIRIDINYLBENZOQUINONES
}

\author{
Bram Prins, ${ }^{*}$ Andries Sj. Koster, Willem Verboom $\dagger$ and David N. Reinhoudt $\dagger$ \\ Department of Pharmacology, Faculty of Pharmacy, University of Utrecht, Catharijnesingel 60, NL- \\ 3511 GH Utrecht, The Netherlands and + Department of Organic Chemistry, University of Twente, \\ P.O. Box 217, NL-7500 AE Enschede, The Netherlands
}

(Received 18 April 1989; accepted 16 May 1989)

\begin{abstract}
Several 2,5-bis(1-aziridinyl)-1,4-benzoquinones (BABQs) can be activated to alkylating species by reduction of the quinone moiety. On the other hand, cytotoxicity of these compounds can be induced by redox cycling. A series of BABOs and their methylated analogues (BMABOs) with different substituents at the 3- and 6-position was synthesized in order to investigate the influence of the substituents on the reduction of the quinone moiety and on the generation of superoxide anion radicals with rat liver microsomes. Superoxide anion production (SAP) ranged from $3.7 \pm 0.1$ to $742 \pm 74$ $\mathrm{nmoles} / \mathrm{min} / \mathrm{mg}$ protein with quinone concentrations of $10 \mathrm{nmoles} / \mathrm{ml}$. NADPH-oxidation was measured under the same conditions and it correlated well $(r=0.88, \mathrm{P}<0.001)$ with SAP. It ranged from $1.4 \pm 0.2$ to $494 \pm 60 \mathrm{nmoles} / \mathrm{min} / \mathrm{mg}$ protein. SAP for $22 \mathrm{~B}(\mathrm{M}) \mathrm{ABQs}$ showed a good correlation with the summated electronic substituent constant $\sigma_{\text {para.total }}(r=0.86, \mathrm{P}<0.001)$. It can be concluded that superoxide anion production by $22 \mathrm{~B}(\mathrm{M}) \mathrm{ABQs}$ in rat liver microsomes can be predicted from structural features of the compounds.
\end{abstract}

The concept of bioreductive activation has been developed since 1972 to explain the antitumor activity of quinone-containing antibiotics [1]. This concept has been used to obtain drugs with selectivity for hypoxic cells [2,3]. Hypoxic cells exist in solid tumors in regions of poor vascularization where a reductive environment might prevail. Since oxygendeficient cells have a limited sensitivity to radiotherapy and most chemotherapy, the development of drugs that are active to hypoxic cells is very important [4]. Well known examples of bioreductively activated cytostatic drugs are the quinone compounds Adriamycin ${ }^{\circledR}$ and mitomycin $C[2,5]$.

At present, two classes of bioreductively activated drugs are in clinical use: the quinone containing alkylating agents in chemotherapy and the hypoxic cell sensitizers (e.g. nitroimidazoles) in radiotherapy [4]. The clinical use of these compounds often is limited by dose-dependent side effects. These effects probably are caused by reactive oxygen intermediates that are formed by redox cycling of the quinone moiety [6]. Based on AZQ $\ddagger$ and related compounds evaluated by Driscoll et al. [7] we synthesized a series of 2,5-bis (1-aziridinyl)-1,4-benzoquinones and methylated analogues (Table 1, Fig. 1). These compounds contain two active parts: the quinone moiety and the alkylating aziridinyl groups. Reduction of the quinone moiety to the hydroquinone facilitates protonation and opening of the

* Author to whom correspondence should be addressed.

$\ddagger$ Abbreviations used: $\mathrm{AZQ}$, diaziquone; $\mathrm{BABQ}, 2,5$ bis(1-aziridinyl)-1,4-benzoquinone; $\mathrm{BMABQ}, 2,5$-bis(2methyl-1-aziridinyl)-1,4-benzoquinone; $C Q$, carboquone; SOD, superoxide dismutase; SAP, superoxide anion production; SCC, succinoylated cytochrome $c$; and Tre, Trenimon. aziridine ring [8]. After one-electron reduction and the formation of a semiquinone reactive oxygen species can be formed by redox cycling of the quinone moiety [10]. Semiquinone formation has been shown to occur for AZQ too [11]. For several quinones it is assumed that superoxide anions formed by redox cycling play an important role in the acute cytotoxicity [12]. In the development of quinone-containing cytostatic drugs it is important to predict these acute effects by redox cycling in an early stage.

In this study we investigated the ability of a series of 2,5-bis(1-aziridinyl)-1,4-benzoquinones for redox cycling with rat liver microsomes. The electrochemical parameters and the antitumor activity of these compounds bearing different substituents at the 3- and 6-position were studied by Driebergen $e t$ al. [8]. The results of measurements of redox cycling are compared with several structural parameters of the substituents.

\section{MATERIALS AND METHODS}

Compounds. The compounds that are used in this study are designated by TW-numbers and presented in Table 1.

BABQ (TW 13), BMABQ (TW 29), 3,6-dichloroBABQ (TW 14), 3,6-dichloro-BMABQ (TW 18), 3,6-dibromo-BABQ (TW 16) and 3,6-dibromoBMABQ (TW 17) were prepared as described previously [13]. 3,6-Difluoro-BABQ (TW 19) 3,6difluoro-BMABQ (TW 20) and 3-(1-aziridinyl)-6fluoro-BABQ (TW 26) were prepared as described by Chou et al. [14]. 3-Methyl-6-bromo-BABQ (TW 22), 3-ethyl-6-bromo-BABQ (TW 25) and 3-[(2carbamoyloxy)-1-ethyl]-6-bromo-BABQ (TW 50), 3 - [2-(carbamoyloxy)-1-ethyl] - 6-methyl - BMABQ (TW 87) were synthesized as described by Nakao et 
Table 1. Aziridinylbenzoquinones with their substituents and structural features [9]

\begin{tabular}{|c|c|c|c|c|c|}
\hline \multirow[b]{2}{*}{ TW nr. } & \multirow[b]{2}{*}{ R1 } & Substituents & \multirow{2}{*}{$\begin{array}{l}\log k^{\prime} \text { (HPLC } \\
\text { capacity factor) }\end{array}$} & \multirow[b]{2}{*}{$\sigma_{\text {para,total }}$} & \multirow{2}{*}{$\begin{array}{l}E_{1 / 2} \\
(\mathrm{mV})\end{array}$} \\
\hline & & R2 & & & \\
\hline & $\mathrm{H}$ & $\mathrm{H}$ & 0.44 & -0.50 & -105 \\
\hline 29-Me & $\mathbf{H}$ & $\mathbf{H}$ & 0.15 & -0.54 & -115 \\
\hline & $\mathrm{Cl}$ & $\mathrm{Cl}$ & 0.35 & -0.04 & -113 \\
\hline 18-Me & $\mathrm{Cl}$ & $\mathrm{Cl}$ & 0.88 & -0.08 & -125 \\
\hline & $\mathrm{Br}$ & $\mathrm{Br}$ & 0.48 & -0.04 & - \\
\hline 17-Me & $\mathrm{Br}$ & $\mathrm{Br}$ & 1.00 & -0.08 & - \\
\hline & $F$ & $\mathrm{~F}$ & -0.15 & -0.38 & -87 \\
\hline 20-Me & $F$ & $\mathrm{~F}$ & 0.44 & -0.42 & -93 \\
\hline 22 & $\mathrm{Br}$ & $\mathrm{CH}_{3}$ & 0.28 & -0.44 & -185 \\
\hline 53-Me & $\mathrm{Br}$ & $\mathrm{CH}_{3}$ & 0.76 & -0.48 & -194 \\
\hline 25 & $\mathrm{Br}$ & $\mathrm{C}_{2} \mathrm{H}_{5}$ & 0.51 & -0.42 & -210 \\
\hline 50 & $\mathrm{Br}$ & $\mathrm{C}_{2} \mathrm{H}_{4} \mathrm{OCONH}_{2}$ & 0.19 & -0.36 & -201 \\
\hline 81 & $\mathrm{Cl}$ & $\mathrm{CH}_{3}$ & 0.20 & -0.44 & -197 \\
\hline Tre & $\mathrm{Az}$ & $\mathrm{H}$ & -0.45 & -0.75 & -171 \\
\hline 26 & $\mathrm{Az}$ & F & -0.31 & -0.69 & -171 \\
\hline $\mathrm{AZQ}$ & \multirow{2}{*}{\multicolumn{2}{|c|}{$\begin{array}{l}\mathrm{NHCO}_{2} \mathrm{C}_{2} \mathrm{H}_{5}(2 \times) \\
\mathrm{NHCO}_{2} \mathrm{C}_{2} \mathrm{H}_{5}(2 \times)\end{array}$}} & -0.48 & -0.80 & -149 \\
\hline 73-Me & & & 0.04 & -0.84 & -145 \\
\hline 32 & $\mathrm{CH}_{3}$ & $\mathrm{C}_{2} \mathrm{H}_{5}$ & 0.29 & -0.82 & -227 \\
\hline 40 & $\mathrm{CH}_{3}$ & $\mathrm{C}_{2} \mathrm{H}_{4} \mathrm{OH}$ & -0.42 & -0.83 & -209 \\
\hline 39 & $\mathrm{CH}_{3}$ & $\mathrm{C}_{2} \mathrm{H}_{4} \mathrm{OCONH}_{2}$ & -0.43 & -0.76 & -213 \\
\hline 87-Me & $\mathrm{CH}_{3}$ & $\mathrm{C}_{2} \mathrm{H}_{4} \mathrm{OCONH}_{2}$ & 0.19 & -0.80 & -235 \\
\hline $\mathrm{CQ}$ & $\mathrm{CH}_{3}$ & $\mathrm{CHOCH}_{3} \mathrm{CH}_{2} \mathrm{OCONH}_{2}$ & 0.44 & -0.74 & -182 \\
\hline
\end{tabular}

$-=$ not measured.

Log $k^{\prime}=$ HPLC capacity factor $\left(r_{r}-r_{\mathrm{o}}\right) / r_{\mathrm{o}}$ for $50 \%$ methanol/0.5 M Na-phosphate $\mathrm{pH}$ 6.5.

$\sigma_{\text {para.total }}=$ summated electronic substituent (Hammett) constant.

$E_{1 / 2}=$ electrochemically determined half wave potential.

$\mathrm{Az}=$ aziridinyl group $\mathrm{Me}=$ methylaziridinyl group<smiles>CCN(C)C</smiles><smiles>CC1CN(C)C1</smiles><smiles>[R]C1=C(N2CC2[R3])C(=O)C([R])=C(N2CC2[R6])C1=O</smiles>

Fig. 1. Chemical structure of aziridinylbenzoquinones. $\mathbf{R}_{1}$ and $R_{2}$ are different substituents and $R_{3}$ is a hydrogen or a methyl group.

al. [15]. 3-Methyl-6-bromo-BMABQ (TW 53) and 3-methyl-6-chloro-BABQ (TW 81) were prepared by treatment of the corresponding 2-halo-5-methyl1,4-benzoquinone with 1-(2-methylaziridine) analogously as described by Nakao et al. [16]. 3-Ethyl-6methyl-BABQ (TW 32), 3-(2-hydroxyethyl)-6methyl-BABQ (TW 40) and its corresponding carbamate ester (TW 39) were prepared as described by Nakao et al. [16]. 3,6-Bis(ethoxycarbonylamino)BMABQ (TW 73) was synthesized according to Khan and Driscoll [17]. AZQ [2,5-bis(1-aziridinyl)3,6 - bis(ethoxycarbonylamino) - 1,4-benzoquinone] was a gift from the Drug Synthesis and Chemistry Branch (National Cancer Institute, Maryland) and $\mathrm{CQ}$ [2,5-bis-(1-aziridinyl)-3-\{2-(carbamoyloxy)-1(methoxyethyl)\}-6-methyl-1,4-benzoquinone] was a gift from the Chemical Research Laboratories (Sankyo Co., Ltd, Tokyo, Japan). 3-(1-Aziridinyl)BABQ (Trenimon) was a gift from Bayer AG (Pharma Research Center, Wuppertal, F.R.G.).

All 22 TW-compounds were freshly dissolved ( $5 \mathrm{mM}$ ) in dimethylsulfoxide (Merck, scintillation grade). Cytochrome $c$ (horse heart, type III) was from Boehringer-Mannheim; NADPH (type X) and SOD (EC 1.15.1.1) were purchased from Sigma Chemical Co., trinitrobenzenesulphonic acid was from Serva and succinic anhydride was from Janssen Chimica.

Methods. Liver microsomes were prepared from male Wistar rats (Hsd/Cpb:WU, Harlan-CPB, Zeist, the Netherlands) in $100 \mathrm{mM} \mathrm{Na-phosphate}$ containing $0.1 \mathrm{mM}$ EDTA pH 7.4. Protein was determined according to Lowry et al. [18]. Partial succinoylation of cytochrome $c$ was performed as described by Kuthan et al. [19]. The initial velocity of the SOD-inhibitable reduction of SCC $(50 \mu \mathrm{M})$ was used for quantitative detection of superoxide 


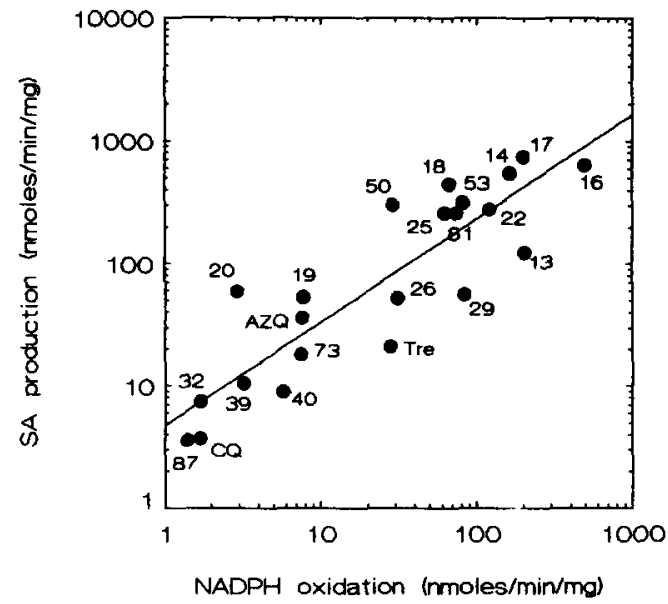

Fig. 2. Microsomal superoxide anion (SA) production (nmoles succinoylated cytochrome $c$ reduction $/ \mathrm{min} / \mathrm{mg}$ protein) vs NADPH oxidation (nmoles $/ \mathrm{min} / \mathrm{g}$ protein) for $22 \mathrm{~B}(\mathrm{M}) \mathrm{ABQs}(10 \mu \mathrm{M})$ under carbogen gassing at $37^{\circ}$ Each point represents the mean of 3 separate measurements for one compound. The numbers refer to the compounds mentioned in Table 1. SAP ranges from 3.7 to 742 nmoles/ $\mathrm{min} / \mathrm{mg}$ and NADPH oxidation ranges from 1.4 to 494 nmoles $/ \mathrm{min} / \mathrm{mg}$

anion radicals. The reduction of SCC at $37^{\circ}$ under $\begin{array}{llll}95 \% & \mathrm{O}_{2} / 5 \% & \mathrm{CO}_{2} & \text { was monitored at } 550 \mathrm{~nm} \text { and }\end{array}$ $\varepsilon_{550}=19.5 \mathrm{mM}^{-1}$ was used for calculations. NADPH-oxidation was performed under the same conditions and monitored at $340 \mathrm{~nm}$. The reactions were carried out in Milli-Q (Millipore) purified water containing $100 \mathrm{mM}$ Na-phosphate $+0.1 \mathrm{mM}$ EDTA $\mathrm{pH} 7.4,10 \mu \mathrm{M} \mathrm{B}(\mathrm{M}) \mathrm{ABQ}$ in dimethylsulfoxide (1\% $\mathrm{v} / \mathrm{v}), \operatorname{SOD}(10 \mathrm{IU} / \mathrm{ml}$, if relevant $), 0.04 \mathrm{mg} / \mathrm{ml}$ microsomal protein and were started with NADPH $(400 \mu \mathrm{M})$. Basal rates of microsomal NADPH-oxidation and SCC reduction were subtracted from quinone-mediated measurements. Statistical analysis was performed using a multivariate least-squares program from SYSTAT [20]. Physicochemical properties (lipophilicity determined as the HPLC capacity ratio $\left(k^{\prime}\right)$ and the electrochemically determined half wave reduction potential $E_{1 / 2}$ ) were taken from Driebergen [9] (see Table 1). Substituent constants for electronic $\left(\sigma_{\text {para }}\right)$ and steric $(\mathrm{MR})$ effects were from Hansch et al. [21] or were calculated by Driebergen [9].

\section{RESULTS}

Without added microsomes no direct reaction was observed between the $\mathrm{B}(\mathrm{M}) \mathrm{ABQs}$ and NADPH or between the $B(M) A B Q s$ and $S C C$. In the presence of NADPH, B(M)ABQs and microsomes the reduction of SCC was inhibited more than $95 \%$ by SOD (10 IU/ $\mathrm{ml}$ ). Superoxide anion production (SAP) was determined for $22 \mathrm{~B}(\mathrm{M}) \mathrm{ABQs}$ at quinone concentrations of $10 \mu \mathrm{M}$. Under nitrogen gassing the reduction of SCC was below $1.0 \mathrm{nmole} / \mathrm{min} / \mathrm{mg}$ for all compounds. Under carbogen gassing SAP ranged from $3.7 \pm 0.1$ to $724 \pm 74 \mathrm{nmoles} / \mathrm{min} / \mathrm{mg}$ protein (Fig. 2). For $4 \mathrm{~B}(\mathrm{M}) \mathrm{ABQs}$ bearing two bromo- or chlorosubstituents (TW 14,18,16,17) the maximal SAP was
Table 2. Microsomal superoxide anion production (SAP) and NADPH-oxidation of 22 aziridinylbenzoquinones under carbogen gassing at $37^{\circ}$. Mean $\pm \mathrm{SE}$

\begin{tabular}{lcc}
\hline TW n. & $\begin{array}{c}\text { SAP } \\
\text { (nmoles/min/mg) }\end{array}$ & $\begin{array}{c}\text { NADPH-oxidation } \\
\text { (nmoles/min/mg) }\end{array}$ \\
\hline 13 & $123 \pm 19$ & $204 \pm 24$ \\
$29-\mathrm{Me}$ & $56 \pm 9$ & $83 \pm 8$ \\
14 & $545 \pm 81$ & $164 \pm 20$ \\
$18-\mathrm{Me}$ & $445 \pm 67$ & $67 \pm 9$ \\
16 & $742 \pm 74$ & $494 \pm 60$ \\
$17-\mathrm{Me}$ & $635 \pm 86$ & $200 \pm 25$ \\
19 & $53 \pm 7$ & $7.7 \pm 1.7$ \\
$20-\mathrm{Me}$ & $59 \pm 8$ & $2.9 \pm 1.3$ \\
22 & $279 \pm 39$ & $121 \pm 23$ \\
$53-\mathrm{Me}$ & $317 \pm 31$ & $81 \pm 8$ \\
25 & $260 \pm 30$ & $62 \pm 8$ \\
50 & $304 \pm 26$ & $29 \pm 6$ \\
81 & $260 \pm 29$ & $74 \pm 7$ \\
Tre & $21 \pm 3$ & $28 \pm 4$ \\
26 & $52 \pm 3$ & $31 \pm 5$ \\
AZQ & $36 \pm 4$ & $7.6 \pm 1.2$ \\
$73-\mathrm{Me}$ & $18 \pm 2$ & $7.5 \pm 1.0$ \\
32 & $7.4 \pm 1$ & $1.7 \pm 0.2$ \\
40 & $8.9 \pm 1$ & $5.7 \pm 0.6$ \\
39 & $10.4 \pm 2$ & $3.2 \pm 0.3$ \\
$87-\mathrm{Me}$ & $3.6 \pm 0.2$ & $1.4 \pm 0.2$ \\
CQ & $3.7 \pm 0.1$ & $1.7 \pm 0.2$ \\
\hline
\end{tabular}

See Table 1 for substituents.

already reached at $10 \mu \mathrm{M}$. BABQs with one or two fluoro-substituents (TW 19,20,26) showed a much lower SAP at this concentration. For BABQs with one bromo- or chloro-substituent (TW $22,25,50,53,81)$ a higher SAP was found at $10 \mu \mathrm{M}$ than with the unsubstituted BABQ (TW 13). The lowest SAP was found for compounds bearing one methyl and one ethyl derivative function (TW $32,39,40, \mathrm{CQ})$. When the SAP of 7 BMABQs was compared with that of the corresponding nonmethylated $\mathrm{BABQs}$ there were 4 that showed no significant difference (Table 2). In contrast TW 29, TW 73 and TW 87 showed a significantly lower SAP at $10 \mu \mathrm{M}$ when compared with the corresponding non-methylated compounds TW 13, AZQ and TW 39.

Microsomal NADPH-oxidation was measured for the 22 compounds; at $10 \mu \mathrm{M}$ it ranged from $1.4 \pm 0.2$ to $494 \pm 60$ nmoles $/ \mathrm{min} / \mathrm{mg}$ (Fig. 2, Table 2). At quinone concentrations of $10 \mu \mathrm{M}$ microsomal NADPH-oxidation correlated well with superoxide anion production $(r=0.88, \mathrm{P}<0.001)$ for the 22 quinones. For most compounds SAP was between 1.0 and 5.0 times NADPH-oxidation (nmoles/ $\mathrm{min} / \mathrm{mg}$ ).

In view of the good agreement of quinonemediated microsomal SAP with NADPH-oxidation we only used SAP for correlations with several experimentally determined physicochemical parameters $\left(\log k^{\prime}, E_{1 / 2}\right)$ and with electronic substituent constants $\left(\sigma_{\text {para,total }}\right)$ describing both the inductive field and the resonance component of the substituents [9]. SAP for $22 \mathrm{~B}(\mathrm{M}) \mathrm{ABQ}$ showed a statistically significant correlation with $\log k^{\prime}(r=0.67$, 


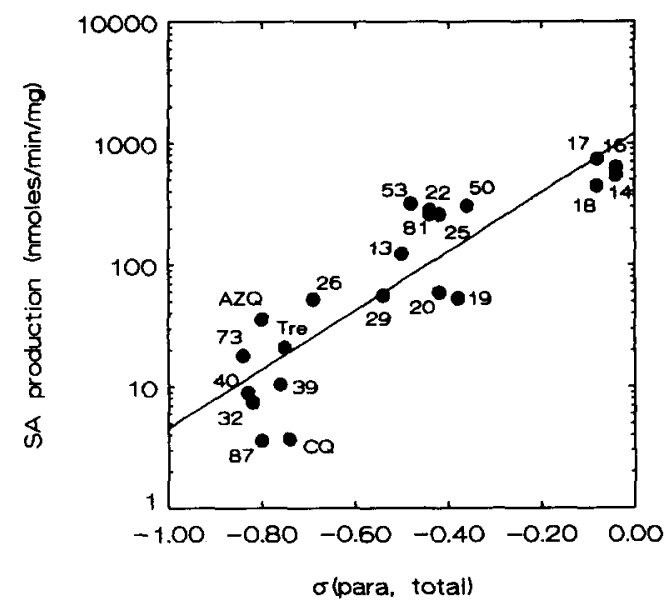

Fig. 3. Microsomal superoxide anion (SA) production (nmoles succinoylated cytochrome $c$ reduction $/ \mathrm{min} / \mathrm{mg}$ protein) vs the electronic substituent constant $\sigma_{\text {para,total }}$ for $22 \mathrm{~B}(\mathrm{M}) \mathrm{ABQs}(10 \mu \mathrm{M})$ under carbogen gassing at $37^{\circ}$. Each point represents the mean of 3 separate measurements for one compound. The numbers refer to the compounds mentioned in Table 1. SAP ranges from 3.7 to $742 \mathrm{nmoles} /$ $\mathrm{min} / \mathrm{mg}$.

$\mathrm{P}=0.001$ ) but the correlation with the electrochemically determined half wave potential $E_{1 / 2}$ was not statistically significant $(r=0.31, \mathrm{P}>0.05)$. However, the correlation of SAP with $E_{1 / 2}$ was considerably improved when compounds with bromoor chloro-substituents were omitted $(\mathrm{N}=13, r=$ $0.72, \mathrm{P}<0.001)$. SAP for $22 \mathrm{~B}(\mathrm{M}) \mathrm{ABQs}$ showed a good correlation with the electronic substituent constant $\sigma_{\text {para }}$ summated for all substituents: $r=0.88$, $\mathrm{P}<0.001$ (Fig. 3). Inclusion of lipophilicity $\left(\log k^{\prime}\right)$ or steric (MR) parameters in a multiple linear regression analysis did not improve this correlation.

\section{DISCUSSION}

Reduction of the quinone moiety is known to initiate the bioactivation of BABQs like $A Z Q$ and $\mathrm{CQ}$ to alkylating agents [11]. Therefore, a series of $\mathrm{BABQs}$ and corresponding $\mathrm{BMABQs}$ was synthesized to investigate the influence of electron-withdrawing and electron-donating substituents on the reduction of the quinone moiety and on the biological activation of these compounds. Their capacity for redox cycling was measured in a microsomal system by the oxidation of NADPH and by the production of superoxide anions (SAP) as measured by the reduction of SCC. The selective inhibition of SCCreduction in the presence of SOD or a nitrogen atmosphere demonstrate that in the presence of $95 \%$ $\mathrm{O}_{2}$ superoxide anions or other reactive oxygen species are formed. The good correlation of quinonemediated SCC-reduction with microsomal NADPHoxidation-both exceeding the quinone concentration-implies that under the chosen conditions $\left(95 \% \mathrm{O}_{2}\right)$ both can be used as parameters for redox cycling of $B(M) A B Q s$. The one-electron reduction by NADPH-cytochrome $\mathrm{P}-450$ reductase may play an important role in the reductive activation of $\mathrm{B}(\mathrm{M}) \mathrm{ABQs}$. This is suggested by the findings of
Powis and Appel [22]. With a series of 1,4-benzoquinones they found a linear relationship beween quinone-dependent superoxide formation by NADPH-cytochrome $\mathrm{P}-450$ reductase and by the hepatic microsomal fraction in the presence of NADPH.

We used experimentally determined physicochemical parameters $\left(\log k^{\prime}\right.$ and $\left.E_{1 / 2}\right)$ and electronic substituent constants (Hammett constant $\sigma_{\text {para }}$ ) [9] to correlate the capacity of $\mathrm{B}(\mathrm{M}) \mathrm{ABQs}$ for redox cycling (SAP, NADPH-oxidation) with structural parameters. The correlation of SAP and $E_{1 / 2}$ was poor, probably because $E_{1 / 2}$ represents a combined 2-electron transfer and protonation by which the hydroquinone is formed. SAP and $E_{1 / 2}$ were better correlated for compounds without bromo- or chlorosubstituents. This can be explained by assuming that these substituents can hinder the protonation or the second electron-transfer [9]. Correlation of SAP with $\log k^{\prime}$ was significant, but it should be noted that for the 22 compounds used $\log k^{\prime}$ and $\sigma_{\text {para,total }}$ are intercorrelated $(r=0.61, \quad \mathrm{P}<0.003)$. However, when the influence of methyl substitution on the aziridinyl functions is considered, no (positive) effect of 2 additional methyl groups on SAP was found despite a considerable positive $(+0.55)$ effect on the $\log k^{\prime}$-value. This is in agreement with the observation of Driebergen et al. [8] that methylation of the aziridines has a minor effect on electrochemical reduction of the quinone ring as measured by the half wave potential.

Concluding, it can be said that the ability of $\mathrm{B}(\mathrm{M}) \mathrm{ABQs}$ for redox cycling, as measured by superoxide anion production and NADPH-oxidation in a microsomal system, can be reasonably predicted from structural features using the electronic substituent constant only. Therefore, introduction of electron-donating substituents in $\mathrm{B}(\mathrm{M}) \mathrm{ABQs}$ diminishes their redox cycling in a microsomal system. Thus, if the production of reactive oxygen radicals is a good predictive parameter for acute cytotoxicity of bioreductively activated quinones the introduction of such substituents could be an effective way of diminishing acute toxic effects.

\section{REFERENCES}

1. Lin AJ, Cosby LA, Shanksky CW and Sartorelli AC, Potential bioreductive alkylating agents. 1. Benzoquinone derivatives. J Med Chem 15: 1247-1252, 1972.

2. Schwartz HS, Mechanisms of selective toxicity of adriamycin, daunomycin and related anthracyclines. In: Molecular Aspects of Anticancer Drug Action (Eds. Neidle S and Waring MJ), pp. 93-104. Verlag Chemie, Weinheim, 1983.

3. Denny WA and Wilson WR, Considerations for the design of nitrophenyl mustards as agents with selective toxicity for hypoxic tumor cells. J Med Chem 29: 879887, 1986.

4. Kennedy KA, Teicher BA, Rockwell S and Sartorelli AC, The hypoxic tumor cell: a target for selective chemotherapy. Biochem Pharmacol 29: 1-8, 1980.

5. Sartorelli AC, The role of mitomycin antibiotics in the chemotherapy of solid tumors. Biochem Pharmacol 35 : 67-69, 1986.

6. Lown JW, The mechanism of action of quinone antibiotics. Molec Cell Biochem 55: 17-40, 1983.

7. Driscoll JS, Dudeck L, Congleton G and Geran RI, 
Potential CNS antitumor agents. VI. Aziridinylbenzoquinones III. J Pharm Sci 68: 185-188, 1979.

8. Driebergen RJ, Holthuis JJM, Hulshoff A, PostmaKelder SJ, Verboom W, Reinhoudt DN and Lelieveld $P$, Electrochemistry of potential bioreductive alkylating quinones: its use in the development of new aziridinylquinones. Anticancer Res 6: 605-620, 1986.

9. Driebergen RJ, Qualitative and quantitative aspects of structure-electrochemistry-cytotoxicity relationships of aziridinylquinones. Ph.D.Thesis, University of Utrecht, 1987.

10. Kappus H, Overview of enzyme systems involved in the bioreduction of drugs and in redox cycling. Biochem Pharmacol 35: 1-6, 1986.

11. Gutierrez PL, Fox BM, Mossoba MM, Egorin M, Nakazawa $\mathrm{H}$ and Bachur NR, Electron spin resonance of electrochemically generated free radicals from diaziquone and its derivatives. Biophys Chem 22: 115123,1985

12. Kappus $\mathrm{H}$ and Sies $\mathrm{H}$, Toxic effects associated with oxygen metabolism: redox cycling and lipid peroxidation. Experientia 11: 1233-1240, 1981.

13. British Patent 762723, Farb Fab Bayer A.-G; CA 51 (1957) 12153 h.: 1956.

14. Chou F, Khan AH and Driscoll JS, Potential central nervous system antitumor agents. Aziridinylbenzoquinones. Part II. J Med Chem 19: 1302-1309, 1976.
15. Nakao $\mathrm{H}$ and Arakawa $\mathrm{M}$, Antileukemic agents. I. Some 2,5-disubstituted $p$-benzoquinones. Chem Pharm Bull 20: 1962-1967, 1972.

16. Nakao $\mathrm{H}$, Arakawa $M$, Nakamura $\mathrm{T}$ and Fukushima $M$, Antileukemic agents. II. New 2,5-bis-(1-aziridinyl)p-benzoquinone derivatives. Chem Pharm Bull 20: 1968-1979, 1972.

17. Khan AH and Driscoll JS, Potential central nervous system antitumor agents. Aziridinylbenzoquinones. Part I. J Med Chem 19: 313-317, 1976.

18. Lowry $\mathrm{OH}$, Rosebrough NJ, Farr AL and Randall RJ, Protein measurement with the Folin phenol reagent, $J$ Biol Chem 193: 265-275, 1951.

19. Kuthan H, Ullrich V and Estabrook RW, A quantitative test for superoxide radicals produced in biological systems. Biochem J 203: 551-558, 1982.

20. SYSTAT, the System for Statistics. Systat Inc., Evanston, IL, 1985.

21. Hansch C, Leo A, Unger SH, Kim KH, Nikaitani $\mathrm{D}$ and Lien EJ, Aromatic substituent constants for structure-activity correlations. J Med Chem 16: $1207-$ 1216, 1973.

22. Powis $G$ and Appel PL, Relationship of the singleelectron reduction potential of quinones to their reduction by flavoproteins. Biochem Pharmacol 29: 2567-2572, 1980. 